\title{
Mixed Oxide Catalyst for the Oxidation of Glycerol to Lactic Acid: Influence of the Preparation Method and Calcination Temperature
}

\author{
Noraini Razali ${ }^{1 *}$ and Ahmad Zuhairi Abdullah ${ }^{2}$ \\ ${ }^{1}$ Faculty of Chemical Engineering, Universiti Teknologi MARA, Cawangan Terengganu, Bukit Besi Campus, 23200, Dungun, \\ Terengganu, Malaysia \\ ${ }^{2}$ School of Chemical Engineering, Universiti Sains Malaysia, Engineering Campus, 14300 Nibong Tebal, Penang, Malaysia
}

* Corresponding author:

tel: $+604-5996411$

email: chzuhairi@usm.my

Received: March 13, 2019

Accepted: July 15, 2019

DOI: $10.22146 / \mathrm{ijc} .44137$

\begin{abstract}
The selective oxidation reaction of glycerol to produce lactic acid is a hightemperature reaction, and requiring a catalyst with high thermal stability. The mixed metal oxide is one of the potential catalysts to be explored. In this study, prepared CaCe supported on $\mathrm{ZrO}_{2}$ catalyst with two preparation methods (co-precipitation and impregnation), and calcination temperatures (800 and $\left.600{ }^{\circ} \mathrm{C}\right)$ were investigated. The oxidation reaction of glycerol to lactic acid was carried out at $250^{\circ} \mathrm{C}$ for $2 \mathrm{~h}$ in a base-free condition using pure glycerol as a reactant. The catalysts were characterized using XRD, TGA, XPS, SEM and basicity test to evaluate and correlate the physical and chemical properties with their catalytic performance. It was found that the catalyst prepared by coprecipitation and calcined at $800^{\circ} \mathrm{C}$ exhibited the highest catalytic performance. The high lactic acid yield of 38.8 and $95 \%$ glycerol conversion were achieved. The catalyst was successfully developed with sufficient porosity and high intensity of mixed metal structure that contributed to the desired high performance. Improvement in the basicity and formation of surface oxygen vacancies was attributed to cationic $\mathrm{Ce}^{4+} / \mathrm{Ce}^{3+}$ elements leading to the promotion of lactic acid yield and high glycerol conversion.
\end{abstract}

Keywords: mixed metal oxide catalyst; oxidation; impregnation; co-precipitation; calcination

\section{- INTRODUCTION}

The production of lactic acid from glycerol has been receiving a lot of attention due to the efficient role of glycerol as a raw material in producing various useful chemicals [1]. Selective oxidation and hydrothermal reactions using solid catalyst have been found as potential techniques to promote high yield and selectivity of lactic acid. Different types of solid catalysts have been studied, such as monometallic, bimetallic, alkaline metal catalyst, alkaline earth metal catalyst, and supported catalyst [2-4].

One important application is the selective oxidation reaction which involves the roles of oxygen capacity in the reaction mechanism. Ceria catalysts feature in a variety of catalytic reactions. $\mathrm{CeO}_{2}$ catalyst has attracted much attention due to its good oxygen storage capacity, thermal resistance and redox promotion property [5-7]. The chemical basicity property of the catalysts was contributed by $\mathrm{CaO}$, as an important modification in the development of mixed oxide catalyst. It was evident that the strong basicity of the catalyst could enhance catalytic dehydration and benzylic acid rearrangement of the dihydroxyacetone intermediates to lactic acid. In addition, Ca leaching could be minimized by coupling with $\mathrm{La}_{2} \mathrm{O}_{3}$ or $\mathrm{CeO}_{2}$ as appropriate support [8].

$\mathrm{ZrO}_{2}$ could be suitable solid support due to its surface catalytic sites properties such as the high concentration of hydroxyl groups and coordinative unsaturated Lewis acidic-basic $\mathrm{Zr}^{+} \mathrm{O}^{2-}$ pairs. These features are believed to potentially enhance the catalytic ability of the transition metal active sites [9]. Thus, this potential has created the interest to explore the suitability of a $\mathrm{CaOCeO} / \mathrm{ZrO}_{2}$ mixed oxide catalyst in the oxidative reaction of glycerol.

According to He et al. [10], the catalyst preparation 
method is a critical factor in determining the interaction between the active metal components and the support. Therefore, it is important to compare the characterization and activity of the catalysts prepared by different synthesis methods and calcination temperatures. Hence, modification of the prepared catalyst would be expected to have an important influence in improving the activity. Thus, incorporation of $\mathrm{CaO}$ and $\mathrm{CeO}_{2}$ into zirconia support seemed to result in a properly mixed oxide catalyst for further study, and its activity can be further improved with necessary modifications.

\section{- EXPERIMENTAL SECTION}

\section{Materials}

Glycerols (98\% purity), calcium nitrate hexahydrate, $\mathrm{Ca}\left(\mathrm{NO}_{3}\right)_{2} \cdot 6 \mathrm{H}_{2} \mathrm{O}$, cerium nitrate hexahydrate, $\left(\mathrm{Ce}\left(\mathrm{NO}_{3}\right)_{2} \cdot 6 \mathrm{H}_{2} \mathrm{O}\right)$, zirconyl chloride octahydrate $\left(\mathrm{ZrOCl}_{2} \cdot 8 \mathrm{H}_{2} \mathrm{O}\right)$, ammonium hydroxide, $\mathrm{NH}_{3} \mathrm{OH}(99 \%$ solution in water), sodium hydroxide, $\mathrm{NaOH}(90 \%)$ and sodium bicarbonate, $\mathrm{Na}_{2} \mathrm{CO}_{3}(90 \%)$ were purchased from Fluka. Deionized water (DI) was used throughout the study for the preparation of the support and catalysts. All chemicals were of reagent grade and were used as received without further purification.

\section{Procedure}

\section{Preparation of mixed oxide catalysts}

Zirconia $\left(\mathrm{ZrO}_{2}\right)$ support was prepared based on a work reported by Yang et al. [11] by using zirconium chloride octahydrate $\left(\mathrm{ZrOCl}_{2} \cdot 8 \mathrm{H}_{2} \mathrm{O}\right)$, and adjusting the $\mathrm{pH}$ of the solution to $10-11$ by dropwise addition of ammonium hydroxide solution (25\%). The sample was then calcined at $500{ }^{\circ} \mathrm{C}$ for $3 \mathrm{~h}$ and used as the catalyst support. The support material was first dispersed in DI water and the required amounts of $\mathrm{Ca}\left(\mathrm{NO}_{3}\right)_{2}$ and $\mathrm{Ce}\left(\mathrm{NO}_{3}\right)_{2}$ solutions were added dropwise under stirring. Then, calculated amounts of $1 \mathrm{M} \mathrm{NaOH}$ and $\mathrm{Na}_{2} \mathrm{CO}_{3}$ were also added dropwise to maintain the $\mathrm{pH}$ at $10-11$. The temperature of the mixture was set at $80^{\circ} \mathrm{C}$ for $5 \mathrm{~h}$ on a hotplate stirrer. The suspension was then filtered, and the solid was thoroughly washed with deionized water to eliminate all traces of base ( $\mathrm{pH}$ test). The catalysts were dried overnight at $80^{\circ} \mathrm{C}$ followed by calcination at either
600 or $800^{\circ} \mathrm{C}$ for $4 \mathrm{~h}$.

Mixed oxide catalysts were also prepared using an impregnation method by mixing the calcined zirconia with an aqueous solution of metal precursors $\left(\mathrm{Ca}\left(\mathrm{NO}_{3}\right)_{2}\right.$ and $\mathrm{Ce}\left(\mathrm{NO}_{3}\right)_{2}$. The number of precursors used was calculated to obtain (30 wt.\%) of active metal loading with a certain ratio of $\mathrm{Ca}$ and $\mathrm{Ce}$. The solution was mixed for $24 \mathrm{~h}$ to ensure that metal dissolved and dispersed thoroughly on the surface of zirconia. The impregnated catalysts were then calcined in a muffle furnace at 600 and $800{ }^{\circ} \mathrm{C}$ for $4 \mathrm{~h}$. The solids obtained were dried in an oven at $120^{\circ} \mathrm{C}$ for $2 \mathrm{~h}$ before use in the oxidation reaction.

\section{Characterization of the catalysts}

The crystalline phases in the prepared catalyst samples and the average crystallite sizes were examined by X-ray diffraction (XRD) method using a Bruker diffractometer operated at $40 \mathrm{kV}$ and $30 \mathrm{~mA}$. The XRD patterns of the samples were obtained using with $\mathrm{CuKa}$ irradiation in the $2 \theta$ range of $5-90^{\circ}$ with a step size of $0.03{ }^{\circ} \mathrm{L}$. Thermal gravimetric analysis (TGA) was performed to observe any significant change in the weight loss of the catalysts. About $5 \mathrm{mg}$ of the catalyst sample was heated from 31 to $800^{\circ} \mathrm{C}$ at a heating rate of $10{ }^{\circ} \mathrm{C} / \mathrm{min}$ in and an airflow of $25 \mathrm{~mL} / \mathrm{min}$ by using simultaneous thermal analyzer (STA, 6000 from PerkinElmer USA).

X-ray photoelectron spectroscopy (XPS) study was carried using an AXIS Ultra DLD system equipped with AlKa X-ray source (1486.6 eV) by Kratos. Both of wide and narrow XPS scan spectra were obtained by scanning a $300 \mathrm{~mm} \times 700 \mathrm{~mm}$ area at $7.5 \times 10^{-9}$ torr ultravacuum environment inside the sample chamber. The analysis was performed using a hybrid lens mode with the slot aperture. The energy of the hemispherical analyzer was set at $160 \mathrm{eV}$ for the survey scan and $20 \mathrm{eV}$ for the narrow scan. The spectra were analyzed by a vision software with vision manager and processing abilities. For background subtraction and curve fitting, a linear method was used. The catalysts surface morphologies were studied utilizing a field emission scanning electron microscope (FESEM Carl Zeiss SMT, Oberkochen, Germany). 


\section{Hammett indicator method}

Hammett indicator method was used to measure the basic strength of the catalyst samples (H_) [12]. In this procedure, $25 \mathrm{mg}$ of the sample was first vigorously dispersed in $5.0 \mathrm{~mL}$ of Hammett indicator solutions and allowed to reach equilibrium for about $2 \mathrm{~h}$ until no significant change in the color intensity was observed. Results were reported as being higher than the weakest Hammett indicator which experienced color change, but lower than the strongest indicator that did not exhibit any color change. The Hammett indicators used in this study were 4-chloroaniline $\left(\mathrm{H}_{-}=26.5\right)$, 4-nitroaniline $\left(\mathrm{H}_{-}=18.4\right)$, 2,4-dinitroaniline $\left(\mathrm{H}_{-}=15.0\right)$, phenolphthalein $\left(\mathrm{H}_{-}=9.3\right)$, bromothymol blue $\left(\mathrm{H}_{-}=7.2\right)$ and neutral red $\left(\mathrm{H}_{-}=6.8\right)$.

\section{Basicity test}

The basicity of the catalysts was determined using Hammett indicator-benzoic acid titration method [13]. First, the $10 \mathrm{mg}$ catalyst was shaken in a conical flask with $2.0 \mathrm{~mL}$ of Hammett indicator solution that had been diluted with methanol. $0.1 \mathrm{~mol} / \mathrm{L}$ benzoic acid was then added dropwise into the conical flask, and the basic catalyst was neutralized using the benzoic acid. When the basic color disappeared, the volume of benzoic acid used was recorded. The basicity ( $\mathrm{mmol} / \mathrm{g}$ ) of solid bases was evaluated by Hammett indicator-benzene carboxylic acid ( $0.02 \mathrm{~mol} / \mathrm{L}$ anhydrous ethanol solution) titration until its color changed back to the original color.

\section{Catalyst activity}

Batch hydrothermal glycerol reaction was carried out in a $50 \mathrm{~mL}$ stainless steel autoclave at a stirring speed of $280 \mathrm{rpm}$. The standard reaction was carried out under the following reaction conditions: $99 \%$ aqueous glycerol, $20 \mathrm{wt} . \%$ of catalyst for $2 \mathrm{~h}$ of reaction. After being purged with $\mathrm{O}_{2}$ for $15 \mathrm{~min}$, the reactor was heated to the desired reaction temperature of $250{ }^{\circ} \mathrm{C}$, and the $\mathrm{O}_{2}$ pressure was maintained at about $7 \mathrm{bar}$. The liquid-phase products were analyzed through a gas chromatograph with a SHODEX capillary column $(50 \mathrm{~m} \times 0.32 \mathrm{~mm} \times 0.25 \mu \mathrm{m})$ and a flame ionization detector. The catalytic performance demonstrated by the catalysts was evaluated based on glycerol conversion as well as the yield and selectivity of lactic acid.

\section{- RESULTS AND DISCUSSION}

\section{Characterization of the Prepared Catalyst}

The XRD analysis confirmed the formation of crystalline $\mathrm{CaO}$ and $\mathrm{CeO}_{2}$ on $\mathrm{ZrO}_{2}$ in the synthesized samples. When prepared by co-precipitation, a solid with two independent phases of the two oxides was formed as indicated by XRD. The latter phase decorates the surface of $\mathrm{ZnO}$ as indicated by a clear role of calcium and cerium in the surface chemistry at $\left(\mathrm{CeO}_{2} \mathrm{ZrO}_{2}\right.$, cubic, $2 \theta=28.3$ and $\left.34.4^{\circ}\right)$ and $\left(\mathrm{CaOZrO}_{2}\right.$, cubic: $2 \theta=60.3$ and $\left.47.5^{\circ}\right)$ of the mixed oxide catalyst. The CaCeZCP catalyst exhibited stronger diffraction peaks than the CaCeZIMP catalysts. Meanwhile, the CaCeZ800 catalyst exhibited higher crystallinity with a more intense peak due to the presence of $\mathrm{CaO}$ and $\mathrm{CeO}_{2}$ phase compared to $\mathrm{CaCeZ600}$ catalyst.

The sizes of the crystalline metal oxides of $\mathrm{CaO}$ and $\mathrm{CeO}_{2}$ were calculated from the XRD diffraction peaks using the Scherrer equation. $\mathrm{CaCeZrO}_{2} \mathrm{CP}$ and $\mathrm{CaCeZrO}_{2} 800$ catalysts exhibited a larger size of crystalline oxides of $\mathrm{CaO}$ and $\mathrm{CeO}_{2}$, with a crystal size of about to $200 \mathrm{~nm}$, while $\mathrm{CaCeZrO}_{2} \mathrm{IMP}$ catalyst exhibited the smaller size of $140 \mathrm{~nm}$. It is shown that the method of preparation and different calcination temperatures affected both the structure and crystalline size of the $\mathrm{CeO}_{2}$ and $\mathrm{CaO}$ in the catalysts (Fig. 1). Increasing calcination temperature to $800{ }^{\circ} \mathrm{C}$ would increase the intensity of XRD reflexes due to the increase in the crystallinity, and it is in agreement with the findings by Al-Fatesh et al. [14].

In addition to the $\mathrm{XRD}$ analysis, thermogravimetric analysis (TGA) was also performed on the $\mathrm{CaCeZrO}_{2}$ systems with the results, as shown in Fig. 2. TGA experiment provided information about water and nitrate ion losses as the catalyst was heated from $0-800^{\circ} \mathrm{C}$. The initial water loss was observed in the temperature range of $0-200^{\circ} \mathrm{C}$, followed by $\mathrm{NO}_{3}{ }^{2-}$ ions decomposition between $600{ }^{\circ} \mathrm{C}$ and $<800{ }^{\circ} \mathrm{C}$. Almost $10 \mathrm{wt} . \%$ mass decrease was observed in this temperature range due to the loss of nitrate ions from the $\mathrm{ZrO}_{2}$ surface.

Nitrate ions contributed greatly to the catalyst's basicity and consequently the catalytic activity. It was, 


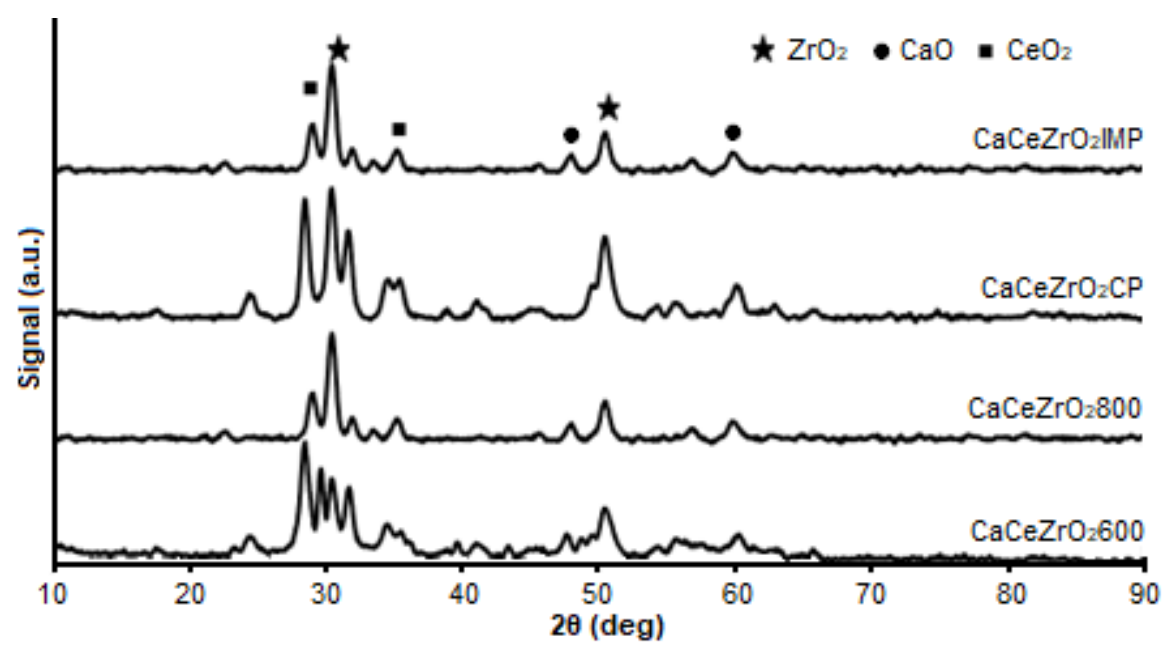

Fig 1. XRD patterns of the prepared catalysts

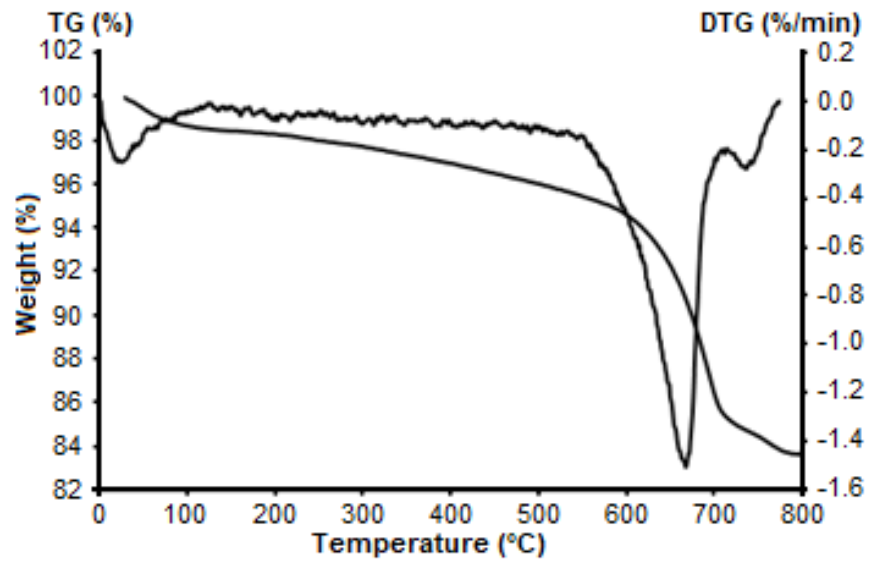

Fig 2. TGA profiles of $\mathrm{CaCeZrO}_{2} 800$ catalyst
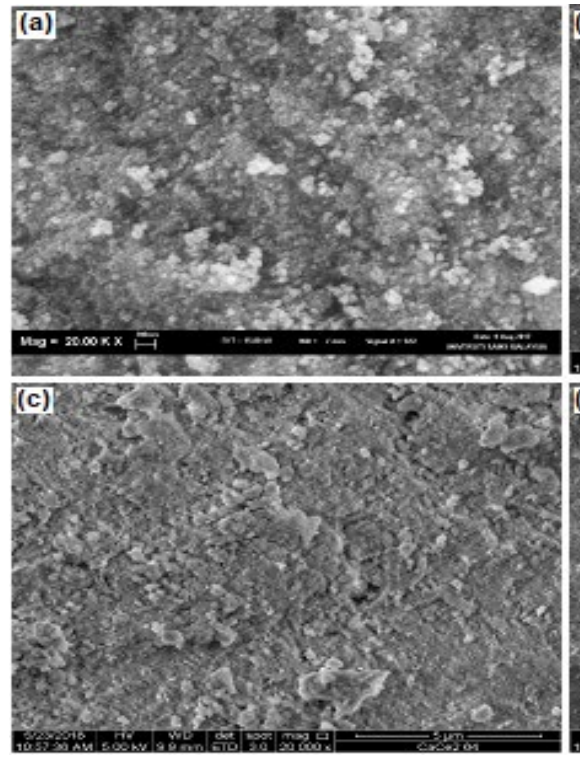

Fig 3. SEM of images at $20.0 \mathrm{k}$ magnification of (a) $\mathrm{CaCeZrO}_{2} 800$ catalysts therefore, important to understand the temperature range of nitrate loss to demonstrate the stability of the catalysts in terms of thermal stability of the synthesized materials. From the results, the catalyst was found to be thermally stable at a temperature of around $800{ }^{\circ} \mathrm{C}$.

A significant change in the morphology was influenced by the preparation method and calcination temperature, as shown in Fig. 3. All of the catalytic materials had different morphologies. $\mathrm{CaCeZrO}_{2} \mathrm{IMP}$ catalyst as shown in Fig. 3(a) appears to have a uniform and quasi-spherical particles with inner-aggregate pores particles. However, as for the $\mathrm{CaCeZrO}{ }_{2} \mathrm{CP}$ catalyst, the

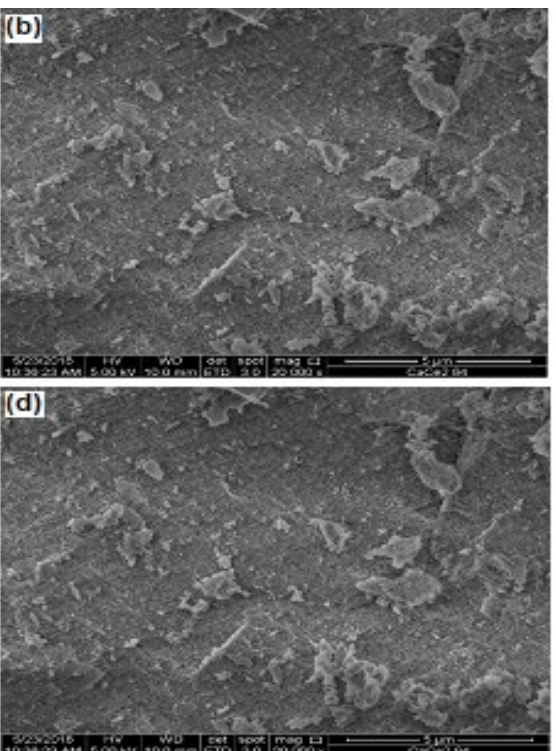

$\mathrm{CaCeZrO}_{2} \mathrm{IMP}$ (b) $\mathrm{CaCeZrO}_{2} \mathrm{CP}$ (c) $\mathrm{CaCeZrO}_{2} 600$ (d) 
aggregates of metal oxide forming small porous structures are visible (Fig. 3(b)).

As the calcination temperature was increased, the morphology of $\mathrm{CaCeZrO}_{2} 600$ (Fig. 3(c)) and $\mathrm{CaCeZrO}_{2} 800$ (Fig. 3 (d)) also showed significant differences. The catalyst calcined at $800^{\circ} \mathrm{C}$ exhibited more uniform and more porous surface suggesting high dispersion of $\mathrm{Ca}$ and $\mathrm{Ce}$ on the $\mathrm{ZrO}_{2}$ support. In addition, calcination process could also contribute to the formation of a hollow, porous, and fluffy product as the reactions that occurred would release large amounts of gas and heat. Ozawa et al. [15] suggested that uniform dispersion of $\mathrm{CeO}_{2}$ over the surface after calcination could result in better dispersion of the active phase. Uniform morphology and crystalline metal of $\mathrm{CaCeZrO}_{2}$ mixed oxide catalyst indicated to the successful preparation method of coprecipitation at high calcination temperature.

Table 1 shows the X-ray photoelectron spectroscopy (XPS) results collected in order to study the chemical composition and state of the mixed oxide catalysts. It shows the XPS spectra in the O 1s, Ce 3d, Ca 2p, and Zr 3d $\mathrm{BE}$ ranges. For $\mathrm{CaCeZrO}_{2} 600$, the $\mathrm{O} 1 \mathrm{~s}$ spectrum shows a peak at 528.7, while for $\mathrm{CaCeZrO}_{2} 800$, the $\mathrm{O}$ 1s spectrum shows a peak at 529.6, and this peak is attributed to chemisorbed oxygen. According to the Piumetti et al. [16], the signal at $528.6-528.9 \mathrm{eV}$ corresponds to $\mathrm{O}$ (i.e. $\mathrm{O}^{2-}$ ), whereas the peak at $529.9-531.4 \mathrm{eV}$ can be ascribed to surface oxygens (i.e. $\mathrm{O}_{2}{ }^{2-}, \mathrm{O}^{-}, \mathrm{OH}^{-}, \mathrm{CO}_{3}{ }^{2-}$ ). For $\mathrm{CaCeZrO}_{2} 800$, the signal related to the $\mathrm{O}$ species appears at a slightly higher BE $(529.6 \mathrm{eV})$; thus, revealing a lower nucleophilicity of the lattice oxygen ions. A richer population of $\mathrm{O}$ species was obtained for high-surface area materials rather than because of the richer population of surface hydroxyls, carbonates and adsorbed oxygen [16]. In the Ce $3 \mathrm{~d}$ region, three peaks within $880-920 \mathrm{eV}$ are recorded at $3 \mathrm{~d}_{5 / 2}$ and $3 \mathrm{~d}_{3 / 2}$. The $\mathrm{Ce}^{3+} / \mathrm{Ce}^{4+}$ content of $\mathrm{CaCeZrO}_{2} 800$ (15.81\%) is higher than that of $\mathrm{CaCeZrO}_{2} 600$ (10.70\%) because of the higher thermal treatment used during the preparation method [16]. The mixed oxide catalyst showed the presence of $\mathrm{CaO}$ and $\mathrm{CeO}$ in both the cationic as well as in the metallic states. The occurrence of cationic Ca species confirms the interaction between $\mathrm{CaO}$ and $\mathrm{CeO}$ nanoparticles, which was expected to lead to $\mathrm{Ce}^{3+} / \mathrm{Ce}^{4+}$ and oxygen deficient sites in the ceria [17].

The $\mathrm{Zr} 3 \mathrm{~d}$ spectra in the $181.9-182.3 \mathrm{eV}$ range denote the $\mathrm{Zr} 3 \mathrm{~d}_{5 / 2}$ state, whereas the signal at $184.4 \mathrm{eV}$ corresponds to the $\mathrm{Zr} 3 \mathrm{~d}_{3 / 2}$ levels. Based on the binding energy of $\mathrm{Zr} 3 \mathrm{~d}_{5 / 2}$, Ce- $\mathrm{Zr}$ mixed oxide can be well distinguished from the $\mathrm{ZrO}_{2}$ phase $(182.9 \mathrm{eV})$ [18]. In the case of powder catalyst, a strong $\mathrm{Ce}-\mathrm{Ca}$ interaction could lead to the formation of $\mathrm{Ce}-\mathrm{Ca}-\mathrm{O}$ mixed oxide system characterized by the enhancement of $\mathrm{Ce}^{3+} / \mathrm{Ce}^{4+}$ ion concentration [18].

The basic properties (basic strength, surface basicity) seemed to influence the catalytic activity. The basicity values obtained by using Hammett indicator and benzoic acid titration were in good agreement with the catalytic activity results. The highest value of basicity $(0.020 \mathrm{mmol} / \mathrm{g})$ produced the highest yield $(38.8 \%)$ and selectivity $(40.6 \%)$ of lactic acid. The conversion of glycerol theoretically increases when the catalyst basicity increases [19]. The basic sites for $\mathrm{CaZrO}_{2}$ and $\mathrm{CeZrO}_{2}$ showed $\mathrm{H}_{-}$in the range of 6.8-7.2. Upon the incorporation of $\mathrm{Ca}$ and $\mathrm{Ce}$, higher basicity, $\mathrm{H}_{-}$in the range of 9.8-15.0 was observed; thus, showing a higher yield of lactic acid due to the surface basic sites value.

Table 1. Summary of XPS results for $\mathrm{CaCeZrO}_{2}$ catalysts calcined at 600 and $800{ }^{\circ} \mathrm{C}$

\begin{tabular}{ccccc}
\hline \multirow{2}{*}{ Catalyst } & \multicolumn{4}{c}{ Binding energy/eV } \\
& $\mathrm{Ce} 3 \mathrm{~d}$ & $\mathrm{O} 1 \mathrm{~s}$ & $\mathrm{Ca} 2 \mathrm{p}$ & $\mathrm{Zr} \mathrm{3d}$ \\
\cline { 2 - 5 } & 895.7 & 528.7 & 345.7 & 181.7 \\
$\mathrm{CaCeZrO}_{2} 600$ & $(10.7)$ & $(46.91)$ & $(10.85)$ & $(7.36)$ \\
& 897.6 & 529.6 & 345.6 & 181.6 \\
$\mathrm{CaCeZrO}_{2} 800$ & $(15.81)$ & $(50.54)$ & $(13.26)$ & $(8.18)$ \\
& & & & \\
\hline
\end{tabular}


Table 2. Performance of the $\mathrm{CaCeZrO}_{2}$ catalysts at different preparation conditions

\begin{tabular}{lccccc}
\hline \multicolumn{1}{c}{ Catalyst } & $\begin{array}{c}\text { Hammett } \\
\text { indicator }\end{array}$ & $\begin{array}{c}\text { Basicity } \\
(\mathrm{mmol} / \mathrm{g})\end{array}$ & $\begin{array}{c}\text { Glycerol } \\
\text { conversion }(\%)\end{array}$ & $\begin{array}{c}\text { Yield } \\
(\%)\end{array}$ & $\begin{array}{c}\text { Selectivity } \\
(\%)\end{array}$ \\
\hline $\mathrm{CaZrO}_{2}$ & $6.8-7.2$ & 0.008 & 96.5 & 29.5 & 30.5 \\
$\mathrm{CeZrO}_{2}$ & $6.8-7.2$ & 0.005 & 96.3 & 28.3 & 29.3 \\
$\mathrm{CaCeZrO}_{2} \mathrm{CP}$ & $9.8-15.0$ & 0.020 & 95.4 & 38.8 & 40.6 \\
$\mathrm{CaCeZrO}_{2} \mathrm{IMP}$ & $9.8-15.0$ & 0.015 & 90.2 & 32.5 & 36.1 \\
$\mathrm{CaCeZrO}_{2} 600$ & $9.8-15.0$ & 0.010 & 95.8 & 29.3 & 30.6 \\
$\mathrm{CaCeZrO}_{2} 800$ & $9.8-15.0$ & 0.020 & 95.4 & 38.8 & 40.6 \\
\hline
\end{tabular}

\section{Performance of the Prepared Catalyst}

The activity of $\mathrm{CaCeZrO}_{2}$ catalysts prepared with two preparation methods and calcination temperatures are shown in Table 2. Catalytic tests showed that $\mathrm{CaCeZrO}_{2}$ catalysts prepared by coprecipitation gave higher glycerol conversion (95.4\%) and lactic acid yield (38.8\%) in comparison to those prepared by impregnation method (90.2\%, 32.5\%, respectively). According to Chen et al. [20], the production of lactic acid requires a strong base with a hydrophilic surface to facilitate the mass transfer between glycerol and the catalyst. It could be due to the fact that the pore structure of calcined catalyst was uniform and it was sufficiently porous to provide sufficient reaction to occur as shown in Fig. 3(a-b). Glycerol was expected to be able to diffuse easily inward into the pores of the catalyst. The interaction with $\mathrm{CaO}$ and $\mathrm{CeO}_{2}$ on the internal and external of the basic sites catalyst surface generated with the cooperation of $\mathrm{CaO}$ and oxygen storage capability of $\mathrm{CeO}_{2}$. The porous morphology and crystalline phase of mixed oxide were confirmed from SEM and XRD analysis results, respectively.

Effects of calcination temperature on the performance of the catalyst were investigated at 600 and $800{ }^{\circ} \mathrm{C}$. Results showed that the conversion of glycerol remained at the same value (95\%), but lactic acid yield increased from 29.30 to $38.80 \%$, for $\mathrm{CaCeZrO}_{2} 600$ and $\mathrm{CaCeZrO} 2800$, respectively. Based on the XPS results, the amounts of $\mathrm{CeO}_{2}, \mathrm{Ca}$ and $\mathrm{O}$ of the catalyst produced with a calcination at $800^{\circ} \mathrm{C}$ were relatively higher $(15.80,13.26$, and $50.54 \%$, respectively) as compared at those of the catalyst calcined at $600{ }^{\circ} \mathrm{C}(10.70,10.85$, and $46.91 \%$, respectively). Thus, the conversion of glycerol to lactic acid was believed to be affected by the amount of active
$\mathrm{CaO}$ and $\mathrm{CeO}_{2}$ with the presence of $\mathrm{ZrO}_{2}$ at high calcination temperature as observed in the XPS results. Sietsma et al. [21] reported that low dispersion of active metal on support was due to the redistribution during drying at low temperature. Al-Fatesh and Fakeeha [22] suggested that high temperature should be employed to ensure sufficient decomposition of the salt used, solid state reactions of the support and reactions between deposited oxides. A nanocrystalline $\mathrm{IrO}_{2}$ structure was studied by Xu et al. [23], and they showed that almost no $\mathrm{IrO}_{2}$ nanoparticles were generated due to amorphous coating that was not fully decomposed at low calcination temperature. Consequently, it affected the total number of active sites available to catalyze their reaction.

Therefore, the highest activity achieved by $\mathrm{CaCeZrO}{ }_{2}$ catalyst was attributed to the significant formation of the desired surface structure of mixed metal oxide formed at a calcination temperature of $800{ }^{\circ} \mathrm{C}$ and prepared with the coprecipitation method.

\section{- CONCLUSION}

Incorporations of calcium and cerium onto the zirconia support led to the formation of an efficient catalyst for lactic acid production from glycerol. High yield of lactic acid (38.80\%) with 95.4\% glycerol conversion was achieved. Investigation on the preparation method of catalyst and calcination temperature revealed the significant influences on the yield of lactic acid and glycerol conversion. Welldeveloped porous structure, high crystallinity of $\mathrm{CaO}$, and $\mathrm{CeO}_{2}$ supported on $\mathrm{ZrO}_{2}$ and basicity properties made it possible to convert glycerol to lactic acid selectively. Thus, the $\mathrm{CaCeZrO}_{2}$ catalyst was deemed and 
suitable for application as a solid catalyst for lactic acid production from glycerol.

\section{- ACKNOWLEDGMENTS}

This work was funded by the Ministry of Higher Education, Malaysia under the Transdisciplinary Research Grant Scheme (TRGS 6762001) and the Fundamental Research Grant Scheme (FRGS 6071366). Noraini Razali gratefully acknowledges the financial support from the Ministry of Higher Education of Malaysia (MOHE) and Universiti Teknologi MARA (UiTM) for her study leave.

\section{- REFERENCES}

[1] Quispe, C.A.G., Coronado, C.J.R., and Carvalho, J.A., 2013, Glycerol: Production, consumption, prices, characterization and new trends in combustion, Renewable Sustainable Energy Rev., 27, 475-493.

[2] Zhao, Z., Arentz, J., Pretzer, L.A., Limpornpipat, P., Clomburg, J.M., Gonzalez, R., Schweitzer, N.M., Wu, T., Miller, J.T., and Wong, M.S., 2014, Volcano-shape glycerol oxidation activity of palladium-decorated gold nanoparticles, Chem. Sci., 5 (10), 3715-3728.

[3] Dimitratos, N., Lopez-Sanchez, J.A., Anthonykutty, J.M., Brett, G., Carley, A.F., Tiruvalam, R.C., Herzing, A.A., Kiely, C.J., Knight, D.W., and Hutchings, G.J., 2009, Oxidation of glycerol using gold-palladium alloy-supported nanocrystals, Phys. Chem. Chem. Phys., 11 (25), 4952-4961.

[4] Chieregato, A., Basile, F., Concepción, P., Guidetti, S., Liosi, G., Soriano, M.D., Trevisanut, C., Cavani, F., and López, J.M.L., 2012, Glycerol oxidehydration into acrolein and acrylic acid over $\mathrm{W}-\mathrm{V}-\mathrm{Nb}-\mathrm{O}$ bronzes with hexagonal structure, Catal. Today, 197 (1), 58-65.

[5] Zeng, S., Zhang, X., Fu, X., Zhang, L., Su, H., and Pan, $\mathrm{H}$., 2013, Co/CexZr $\mathrm{r}_{1-\mathrm{x}} \mathrm{O}_{2}$ solid-solution catalysts with cubic fluorite structure for carbon dioxide reforming of methane, Appl. Catal., B, 136-137, 308-316.

[6] Kambolis, A., Matralis, H., Trovarelli, A., and Papadopoulou, C., 2010, Ni/ $\mathrm{CeO}_{2}-\mathrm{ZrO}_{2}$ catalysts for the dry reforming of methane, Appl. Catal., A, 377 (12), 16-26.

[7] Maciel, C.G., Silva, T.F., Hirooka, M.I., Belgacem, M.N., and Assaf, J.M., 2012, Effect of nature of ceria support in $\mathrm{CuO} / \mathrm{CeO}_{2}$ catalyst for PROX-CO reaction, Fuel, 97, 245-252.

[8] Kim, M., DiMaggio, C., Yan, S., Salley, S.O., and Ng, K.Y.S., 2011, The effect of support material on the transesterification activity of $\mathrm{CaO}-\mathrm{La}_{2} \mathrm{O}_{3}$ and $\mathrm{CaO}-$ $\mathrm{CeO}_{2}$ supported catalysts, Green Chem., 13 (2), 334339.

[9] Kim, Y.H., Hwang, S.K., Kim, J.W., and Lee, Y.S., 2014, Zirconia-supported ruthenium catalyst for efficient aerobic oxidation of alcohols to aldehydes, Ind. Eng. Chem. Res., 53 (31), 12548-12552.

[10] He, Y., Ford, M.E., Zhu, M., Liu, Q., Wu, Z., and Wachs, I.E., 2016, Selective catalytic reduction of $\mathrm{NO}$ by $\mathrm{NH}_{3}$ with $\mathrm{WO}_{3}-\mathrm{TiO}_{2}$ catalysts: Influence of catalyst synthesis method, Appl. Catal., B, 188, 123133.

[11] Yang, G.Y., Ke, Y.H., Ren, H.F., Liu, C.L., Yang, R.Z., and Dong, W.S., 2016, The conversion of glycerol to lactic acid catalyzed by $\mathrm{ZrO}_{2}$-supported $\mathrm{CuO}$ catalysts, Chem. Eng. J., 283, 759-767.

[12] Kouzu, M., Kasuno, T., Tajika, M., Sugimoto, Y., Yamanaka, S., and Hidaka, J., 2008, Calcium oxide as a solid base catalyst for transesterification of soybean oil and its application to biodiesel production, Fuel, 87 (12), 2798-2806.

[13] Huaping, Z., Zongbin, W., Yuanxiong, C., Ping, Z., Shijie, D., Xiaohua, L., and Zongqiang, M., 2006, Preparation of biodiesel catalyzed by solid super base of calcium oxide and its refining process, Chin. J. Catal., 27 (5), 391-396.

[14] Al-Fatesh, A.S., Fakeeha, A.H., Ibrahim, A.A., Khan, W.U., Atia, H., Eckelt, R., Seshan, K., and Chowdhury, B., 2016, Decomposition of methane over alumina supported $\mathrm{Fe}$ and $\mathrm{Ni}-\mathrm{Fe}$ bimetallic catalyst: Effect of preparation procedure and calcination temperature, J. Saudi Chem. Soc., 22 (2), 239-247.

[15] Ozawa, M., Takahashi-Morita, M., Kobayashi, K., and Haneda, M., 2017, Core-shell type ceria zirconia support for platinum and rhodium three way catalysts, Catal. Today, 281, 482-489.

[16] Piumetti, M., Bensaid, S., Fino, D., and Russo, N., 2016, Nanostructured ceria-zirconia catalysts for 
CO oxidation: Study on surface properties and reactivity, Appl. Catal., B, 197, 35-46.

[17] Purushothaman, R.K.P., van Haveren, J., van Es, D.S., Melián-Cabrera, I., Meeldijk, J.D., and Heeres, H.J., 2014, An efficient one pot conversion of glycerol to lactic acid using bimetallic gold-platinum catalysts on nanocrystalline $\mathrm{CeO}_{2}$ support, Appl. Catal., B, 147, 92-100.

[18] Reddy, B.M., and Khan, A., 2003, Structural characterization of $\mathrm{CeO}_{2}-\mathrm{TiO}_{2}$ and $\mathrm{V}_{2} \mathrm{O}_{5} / \mathrm{CeO}_{2}-\mathrm{TiO}_{2}$ catalysts by Raman and XPS techniques, J. Phys. Chem. B, 107 (22), 5162-5167.

[19] Atia, H., Armbruster, U., and Martin, A., 2011, Influence of alkaline metal on the performance of supported silicotungstic acid catalysts in glycerol dehydration towards acrolein, Appl. Catal., A, 393 (1-2), 331-339.

[20] Chen, L., Ren, S., and Ye, X.P., 2014, Lactic acid production from glycerol using $\mathrm{CaO}$ as a solid base catalyst, Fuel Process. Technol., 120, 40-47.

[21] Sietsma, J.R.A., Friedrich, H., Broersma, A., Versluijs-Helder, M., van Dillen, A.J., de Jongh, P.E., and de Jong, K.P., 2008, How nitric oxide affects the decomposition of supported nickel nitrate to arrive at highly dispersed catalysts, $J$. Catal., 260 (2), 227-235.

[22] Al-Fatesh, A.S., and Fakeeha, A.H., 2012, Effects of calcination and activation temperature on dry reforming catalysts, J. Saudi Chem. Soc., 16 (1), 55-61.

[23] Xu, W., Haarberg, G.M., Sunde, S., Seland, F., Ratvik, A.P, Zimmerman, E., Shimamune, T., Gustavsson, J., and Åkre, T., 2017, Calcination temperature dependent catalytic activity and stability of $\mathrm{IrO}_{2}-\mathrm{Ta}_{2} \mathrm{O}_{5}$ anodes for oxygen evolution reaction in aqueous sulfate electrolytes, $J$. Electrochem. Soc., 164 (9), 895-900. 